\title{
IMPLEMENTASI PROGRAM BANTUAN OPERASIONAL SEKOLAH
}

\author{
Anggriati Ledu Ngaba \\ Universitas Kristen Satya Wacana \\ Jalan Diponegoro, No. 52-60, Salatiga, Sidorejo, Kota Salatiga, Jawa Tengah 50714 \\ 942016028@student.uksw.edu
}

\begin{abstract}
The aim of research is to analyze the implementation of the program of school operational assistance (BOS) on one Christian Primary School, West Sumba at the stage of preparation and implementation. The research method is descriptive with case studies. The technique of collecting data using interviews and document study. The analysis showed of BOS program implementation at the stage of preparation has been good, but the Decree of BOS management team is not published. The implementation stage is already very good but slow disbursement of funds from the government, transparency is good enough that involve committees and parents, accountability is good that is planning the use of funds in accordance with the format specified, the school also orderly administration accountability report, but not announced.
\end{abstract}

Keywords: BOS Program, Implementation, Christian Elementary School

\begin{abstract}
Abstrak : Tujuan penelitian adalah menganalisis implementasi program bantuan operasional sekolah pada salah satu Sekolah Dasar Masehi, Sumba Barat Dayapada tahap persiapan danpelaksanaan.Metode penelitian yaitu deskriptif dengan studi kasus. Teknik pengumpulan data menggunakan wawancara dan studi dokumen. Hasil analisis menunjukkan implementasi program BOS pada tahap persiapan sudah bagus,tetapiSK tim manajemen BOS tidak diterbitkan. Tahap pelaksanaan sudah sangat baik tetapi pencairan dana dari pemerintah lambat, transparansi sudah cukup baik yaitu melibatkan komite dan orang tua, akuntabilitas sudah bagus yaitu menyusun perencanaan penggunaan dana sesuai dengan format yang ditentukan, sekolah juga tertib dalam administrasi laporan pertanggungjawaban, tetapi tidak diumumkan.
\end{abstract}

Kata kunci: Program BOS, Implementasi, Sekolah Dasar Masehi

Pendidikan adalah investasi jangka panjang yang menentukan keberlangsungan kehidupan bangsa yang beradap, berakhlak, dan berkarakter. Hal tersebut dilakukan secara berkelanjutan dari pendidikan dasar hingga pendidikan tinggi, sehingga pendidikan yang diperoleh akan sangat menentukan masa depan seseorang. Pendidikan juga menentukan kemajuan, meningkatkan kualitas dan pembangunan sebuah negara sehingga negara mempunyai kewajiban mencerdaskan kehidupan bangsanya melalui pendidikan. Pemerintah Indonesia mengamanatkan dalam Undang-Undang Dasar Republik Indonesia Tahun 1945 Pasal 31 Ayat 1 menyatakan bahwa setiap warga negara berhak untuk mendapat pendidikan dan ayat 2 menyatakan bahwa Setiap warga negara wajib mengikuti pendidikan dasar dan pemerintah wajib membiayainya. Selain itu, UU SISDIKNAS Pasal 11 ayat 1 menyatakan bahwa Pemerintah dan Pemerintah Daerah wajib memberikan layanan dan kemudahan, serta menjamin 
terselenggaranya pendidikan yang bermutu bagi setiap warga negara tanpa diskriminasi; dan ayat 2 menyatakan bahwa Pemerintah dan Pemerintah Daerah wajib menjamin tersedianya dana guna terselenggaranya pendidikan bagi setiap warga negara yang berusia tujuh sampai dengan lima belas tahun. Salah satu upaya yang dilakukan pemerintah dalam melaksanakan amanat tersebut adalah dengan adanya Program Bantuan Operasional Sekolah (BOS).

Program Bantuan Operasional Sekolah merupakan program pemerintah denganmenyediakan pendanaan biaya operasi nonpersonalia bagi satuan pendidikan dasar sebagai pelaksana program wajib belajar. Semua SD/SDLB, SMP/SMPLB/ SMPT yang menerima dana BOS membebaskan pungutan bagi seluruh peserta didik terhadap biaya operasional sekolah dan membebaskan pu-ngutan dalam bentuk apapun bagi seluruh peserta didik miskin dan meringankan beban biaya operasi sekolah bagi peserta didik di sekolah negeri maupun swasta. Program BOS dimulai sejak bulan Juli 2005 berperan secara signifikan dalam percepatan pencapaian wajib belajar. Sehingga sejak tahun 2009 pemerintah melakukan perubahan tujuan, pendekatan dan orientasi pada program BOS, dari perluasan akses menuju pada peningkatan kualitas. Program Bantuan Operasional Sekolahpada setiap tahunnya mengalami peningkatan biaya satuan sertaperubahan mekanisme dalam penyaluran, dan mulai tahun 2012 penyaluran dana BOS dilakukan melalui mekanisme transfer ke provinsi dan selanjutnya ditransfer ke rekening sekolah secara langsung dalam bentuk hibah.

Dalam implementasinya, masih banyak pihak yang kurang memahami untuk apa saja dan bagaimana penggunaan dana BOS dan seringkali menjadi beban bagi pihak sekolah dalam hal ini bendahara maupun kepala sekolah sebagai pihak yang bertanggung jawab dalam penggunaan dana BOS. Purwanti (2014: 353) berpendapatbahwa, dalam lingkup sekolah dasar terdapat tugas tambahan yang diberikan kepada guru yaitu sebagai bendahara BOS.

Keterlambatan masuknya dana BOS ke rekening juga merupakan masalah yang dihadapi oleh sekolah hal ini terlihat dari hasil penelitian yang dilakukan oleh Lika yang berjudul Implementasi Program Bantuan Operasional Sekolah (BOS) pada Sekolah Dasar Negeri 003 Melak Kabupaten Kutai Barat. Hal serupa juga terjadi di salah satu
Sekolah Dasar Masehi yang menerima dana BOS. Berdasarkan hasil wawancara terhadap kepala sekolah, bendahara dan seorang guru, terdapat kendala dan masalah dalam pelaksanaan BOS di Sekolah ini seperti adanya keterlambatan dana BOS sehingga penyaluran dana BOS tidak tepat waktu, sehingga sekolah dalam hal ini bendahara sering mengalami kesulitan dalam pembuatan kwitansi belanja untuk pertanggungjawaban. Oleh karena itu, penulis ingin melakukan penelitian untuk menganalisis apakah implementasi Program BOS pada tahap persiapan/perencanaan, dan pelaksanaannya sudah sesuai dengan standar pelaksanaan program yang telah ditetapkan, serta mengidentifikasi halhal yang mempengaruhi implementasi program di sekolah tersebut.

\section{METODE}

Penelitian ini bertujuan untuk mendeskripsikan atau menjelaskan implementasi progran dana BOS khususnya berkaitan dengan kesesuaian antara implementasi yang dilakukan dan peraturan atau ketentuan yang telah ditetapkan. Implementasi yang menjadi fokus penelitian ini terdiri dari 1) tahap persiapan. dan 2)tahap pelaksanaan. Pendekatan dalam penelitian menggunakan kualitatif, dengan rancangan studi kasus.Subjek penelitian adalah salah satu Sekolah Dasar Masehi di Sumba Barat DayaProvinsi Nusa Tenggara Timur. Teknik pengumpulan data adalah wawancara dan studi dokumen. Data dianalisis melalui 3 alur yaitu reduksi data, penyajian data, dan penarikan kesimpulan dan verifikasi (Sugiono, 2015).

\section{HASIL}

Berdasarkan hasila nalisis data yang mengacu kepada fokus penelitian, yaitu:

\section{1) Tahap Persiapan}

sebagai langkah awal dalam mengelola dana BOS, sekolah diwajibkan membentuk Tim Manajemen BOS Sekolah. Berdasarkan hasil wawancara terhadap Kepala Sekolah dan Bendahara, struktur Tim Manajemen Sekolah pada Tahun 2016 cenderung sama dengan strktur tim pada tahun sebelumnya (sekolah sudah mengelola dna BOS sejak tahun 2005). Hal ini terlihat dari susunan tim yang masih sama dengan tahun-tahun sebelumnya yang terdiri dari Kepala Sekolah 
selaku penanggungjawab, bendahara, dua orang guru, dan salah satu orang tua murid. Kepala Sekolah dan bendahara biasanya disebut sebagai tim inti. Dalam melaksanakan tugasnya, tim inti tersebut banyak dibantu oleh operator sekolah. Operator sekolah ini membantu bendahara dalam pembuatan laporan keuangan dan juga input data siswa. Keberadaan Komite sekolah, salah satu orang tua siswa, dan 2 orang guru dalam struktur tim manajemen BOS biasanya hanya terlibat pada tahap perencanaan yaitu penyusunan dan pengesahan Rencana Kerja dan Anggran Sekolah (RKAS).

Setelah Tim Manajemen Bos ditentukan, Kepala Sekolah mempunyai kewajiban mengesahkan tim tersebut dengan menerbitkan Surat Keputusan (SK), dalam praktiknya, Kepala Sekolah hanya menerbitkan SK untuk Bendahara, Kepala Sekolah berpendapat bahwa hanya bendahara yang diterbitkan SK sedangkan anggota lain tidak perlu. Hal yang senada juga dinyatakan oleh salah satu guru bahwa sekolah tidak menerbitkan SK khusus untuk pengelola BOS selain bendahara. Tidak diterbitkannya SK untuk semua Tim BOS oleh Kepala Sekolah menunjukkan adanya kesalahpahaman mengenai ketentuan dalam mekanisme pembentukan tim.

Pada tahap persiapan, salah satu kegiatan yang dilakukan tim manajemen BOS adalah melakukan sosialisasi program BOS. Sosialisasi ini merupakan tahap yang penting karena melalui sosialisasi ini informasi-informasi terkait dengan implementasi Program BOS di sekolah dapat disampaikan, selain itu sosialisasi juga menjadi sarana komunikasi berkaitan dengan pelaksanaan program BOS. Program sekolah gratis memunculkan rasa ingin tahu tentang dana BOS secara tidak langsung karena ketika sekolah menerima dana BOS, hanya dana itu yang menjadi sumber pendapatan sekolah. Dampak program sekolah gratis yang dirasakan langsung oleh guru adalah hilangnya beberapa pos insentif seperti tunjangan uang transport, insentif sebagai wali kelas, dan lain-lain, yang selama ini dibiayai menggunakan dana sumbangan komite. Selain itu pada ketentuannya dana BOS tidak boleh digunakan untuk memberikan insentif bulanan untuk kegiatan yang sudah menjadi tugas guru. Sehingga sekolah merasa perlu menyampaikan informasi tentang dana BOS kepada guru-guru agar dapat memahami perubahan yang terjadi di sekolah melalui sosialisai.
Sosialisasi kepada guru selain memberi pemahaman tentang dana BOS, jugamembantu guru ketika menjelaskankepada orang tua siswa dalam hal pembiayaan pendidikan di luar kepentingan operasional. Sosialisasi kepada guru-guru dilakukan ketika rapat dewan guru yang diselenggarakan sekolah. Sosialisai kepada orang tua siswa dilakukan pada saat rapat orang tua murid setiap awal tahun ajaran. Hal yang disampaikan meliputi jumlah dana BOS yang diterima oleh sekolah dan penggunaannya. Terkadang penyampaian berkaitan penjelasan tentang adanya kebutuhan tertentu yang tidak bisa dibiayaidana BOS sehingga orang tua harus ikut berpartisipasi dalam pembiayaan tersebut. Kondisi seperti ini terjadi ketika bangunan yang membutuhan renovasi tetapi tidak cukup dana dan sekolah sudah mendapat giliran dana DAK. Menangani masalah ini, sekolah melibatkan komite sekolah dan orang tua siswa untuk membantu memenuhi kekurangan biaya renovasi dan pembangunan. Pada dasarnya dana untuk sosialisasi BOS secara khusus tidak dialokasikan. Oleh karena itu, pada tingkat sekolah, sosialisasi "disatukan"e pada rapat-rapat sekolah.

\section{2) Tahap Pelaksanaan}

Tahap pelaksanaan membahas tentang kegiatan pengajuan dana BOS, penggunaan BOS, dan upaya-upaya transparansi dan akuntabilitas. Pada kegiatan pengajuan dana BOS, sekolah melakukan pendataan jumlah siswa serta validasi data siswa yang kemudian disampaikan kepada Tim Manajemen BOS Kabupaten. Menyusun RKAS (Rencana Kegiatan dan Anggaran Sekolah) dengan melibatkan beberapa pihak seperti kepala sekolah, bendahara, ketua komite, serta dewan guru. Penyusunan rencana penggunaan dana BOS dilakukan pada awal tahun anggaran dan disesuaikan dengan JUKNIS. Selain terlibat dalam penyusunan rencana penggunaan dana BOS, Komite juga berperan dalam mengawasi, memantau dan mendukung program BOS. Selanjutnya adalah pengusulan dana BOS yang dimulai dengan verifikasi data oleh sekolah. Ketika mengusulkan pencairan dana sekolah harus melampirkan pertanggungjawaban dana termin sebelumnya untuk dapat mencairkan dana pada termin berikutnya. Persyaratan bahwa sebelum mencairkan dana pada termin berikutnya sekolah harus menyerahkan pertanggungjawaban dana diterima dan ditanggapi positif oleh sekolah meskipun pengaturan itu tidak ada dalam buku 
panduan. Sekolah melihat hal tersebut sebagai upaya menerapkan tertib dan disiplin administrasi sekolah dalam mempertanggungjawabkan penggunaan dana. Melalui peraturan tersebut sekolah seperti dipaksa untuk membuat laporan pertanggung jawaban secepatnya sehingga tidak mengalami keterlambatan pencairan dana.

Berdasarkan uraian di atas, pengajuan dan penyaluran dana BOS dapat digambarkan sebagai berikut: Tahap pengusulan dana BOS oleh sekolah dimulai dengan verifikasi data, pengusulan dana dilampiri daftar dan jumlah siswa kepada Tim Manajemen BOS Kabupaten. Berdasarkan data tersebut, Tim Manajemen Kabupaten menerbitkan Surat Perjanjian Pemberian Bantuan (SPPB) dan mencantumkan jumlah dana BOS yang diterima sekolah pada satu periode penyaluran. Selanjutnya, sekolah menandatangani SPPB tersebut dan menyerahkan kembali dengan melampirkan laporan pertanggungjawaban (SPJ) penggunaan dana BOS pada pencairan sebelumnya.

Tahap penggunaan dana BOS dilakukan oleh sekolah sesuai dengan ketentuan penggunaan dana BOS yang diatur dalam petunjuk teknis pelaksanaan. Sejauh ini sekolah merasa dana cukup memenuhi kebutuhan sekolah. Sekolah dalam menggunakan dana BOS memprioritaskan beberapa kegiatan seperti pembiayaan honor guru/ tenaga pendidik/ kependidikan yaitu 30\% dari dana BOS yang diterima sekolah, pembiayaan kegiatan ekstrakurikuler, kegiatan O2SN (Olimpiade Olahraga Siswa Nasional), lomba MIPA (Matematika dan Ilmu Pengetahuan Alam), lomba mata pelajaran, belanja barang habis pakai seperti ATK kantor/sekolah dan keperluan rumah tangga sekolah, layanan daya dan jasa seperti langganan listrik dan modem, pengadaan buku materi kelas I-VI. Pembelian barang disesuaikan dengan jumlah yang direncanakan dalam RKAS (Rencana Kegiatan dan Anggaran Sekolah) yang disertai dengan kwitansi atau nota belanja.

Penggunaan dana BOS secara keseluruhan berdasarkan laporan pertanggungjawaban sekolah, maka kecenderungan pengeluaran dana BOS dapat diklasifikasikan dalam tiga kelompok utama yaitu Honorarium, Transportasi, dan ATK+foto copy. Ketiga kelompok pengeluaran ini hampir dikatakan menjadi pengeluaran rutin setiap bulan meskipun untuk kegiatan yang berbeda-beda, sehingga secara keseluruhan penggunaan dana BOS tidak ada yang menyimpang dari ketentuan dalam panduan
BOS. Tetapi untuk memenuhi kebutuhan sekolah berkaitan dengan komponen yang tidak dibiayai dana BOS seperti renovasi atau pembangunan sekolah, disinilah peran komite sekolah dan orang tua siswa. Melalui program komite sekolah, orang tua siswa siap untuk memberikan sumbangan untuk memenuhi kebutuhan tersebut, salah satu yang dilakukan oleh komite sekolah dan orang tua murid adalah pembongkaran gedung sekolah lama dan menjadikannya lapangan yang luas untuk kegiatan upacara sekolah, selain itu, komite sekolah dan orang tua muris juga bekersa sama dalam pembangunan ulang agar sekolah yang sudah rusak. Semua biaya yang dibutuhkan adalah hasil iuran sukarelal dari orang tua siswa pada setiap bulannya.

Pada tahap pelaksanaan ada beberapa masalah yang dihadapi bendahara terkait dengan penggunaan dana BOS, salah satunya adalah masalah keterlambatan pencairan dana BOS. Keterlambatan ini berakibat pada tidak tersedianya dana pada saatkegiatan harus dilakukan. Contohnya adalah, ketika kegiatan O2SN dilakukan, dana BOS belum tersedia sehingga berakibat pada penggunaan dana pribadi demi kelancaran kegiatan dan akan diganti ketika dana BOS tesedia. Hal ini juga menjadi kendala tersendiri bagi bendahara berkaitan dengan pembuatan kwitansi belanja untuk pertanggungjawaban penggunaan dana. Sehingga solusi yang selama ini dilakukan oleh bendahara adalah dengan mengambil nota atau kwitansi belanja tanpa mencantumkan tanggal.

Upaya transparansi yang dilakukan oleh sekolah dalam pengelolaan dana BOS terlihat dari susunan Tim Manajemen BOS Sekolah yang memasukkkan unsur orang tua siswa selain komite sekolah serta keterlibatan komite sekolah dalam pembuatan RKAS sampai pada pencairan dana BOS. Penyususnan RKAS dilakukan sesuai dengan format baku dari Dinas Pendidikan Kabupaten, ditandatangani oleh Kepala Sekolah dan Ketua Komite Sekolah. Upaya transparansi yang dilakukan sekolah hanya sebatas melibatkan komite sekolah dalam penysunan dan pengelolaan dana BOS, berdasarkan hasil wawancara mendalam, sekolah tidak melakukan tanggungjawab sesuai dengan panduan seperti mengumumkan besar dana yang diterima serta rencana penggunaan dana BOS yang ditandatangani kepala sekolah, bendahara dan komite sekolah pada papan pengumuman, 
hal ini sempat dilakukan oleh sekolah tetapi hanya dilakukan pada awal-awal tahun menerima dana BOS. Hasil ini menunjukkan bahwa upaya transparansi dalam bentuk pengumuman program di sekolah selama ini cenderung kurang dilakukan secara baik.

Panduan pengunaan dana BOS mensyaratkan adanya pengelolaan dana BOS secara akuntabel. Upaya akuntabilitas yang dilakukan sekolah hanya terlihat dari pengisian format sesuai dengan kebutuhan dalam tahapan pelaksanaan program dengan harapan bahwa sekolah dapat melaksanakan tertib administrasi pada setiap tahapan dan menjunjung tinggi akuntabiitas, tetapi dengan tidak dilaksanakannya pemasangan pengumuman penggunaan dana BOS di sekolah maka akuntabilitas pengelolaan sebagaimana diwajibkan dalam panduan cenderung tidak terlaksana dengan baik, seperti mengumumkan laporan bulanan pengeluaran dana BOS dan barang-barang yang dibeli oleh sekolah di papan pengumuman setiap tiga bulan. Namun di sisi lain, untuk pertanggungjawaban secara formal tentang pengelolaan dana BOS, sekolah terikat peraturan dari Dinas Pendidikan (Tim Manajemen Kabupaten) yang mewajibkan adanya laporan pertanggungjawaban dana (SPJ) sebelum mencairkan termin berikutnya dilakukan dengan baik. Dampak positif aturanadalah sekolah menjadi lebih tertib dan disiplin dalam menyerahkan laporan meskipun bukan dilatarbelakangi oleh sebuah kesadaran namun karena sekolah berkepentingan untuk pencairan dana termin berikutnya. Ditinjau dari sisi akuntabilitas, ditemukan adanya semacam good practice dalam pengelolaan program BOS, yaitu peraturan bahwa laporan pertanggungjawaban dana harus diserahkan sebelum mencairkan dana berikutnya. Bila sekolah terlambat menyerahkan laporan maka akan berakibat pada penyaluran dana BOS termin berikutnya. Langkah ini memacu disiplin sekolah dalam hal penyusunan laporan.

\section{PEMBAHASAN}

Van Meter dan Van Horn (dalam Winarno, 2002:146) mengemukakan bahwa implementasi merupakan tindakan-tindakan oleh individu atau kelompok pemerintah maupun swasta yang diarahkan untuk mencapai tujuan yang telah ditetapkan dalam keputusan suatu program atau kebijakan Ini berarti bahwa implementasi adalah apa yang terjadi setelah suatu program atau kebijakan ditetapkan, sehingga istilah implementasi merunjuk pada kegiatan mengikuti pernyataan atau tujuan-tujuan serta hasil-hasil oleh akor pelaksana sesuai yang diinginkan pemerintah atau perumus program atau kebijkan.

Grindle (dalam Winarno, 2002:146) mempunyai pendapat bahwa umumnya tugas implementasi adalah membentuk suatu ikatan (linkage) yang memudahkan realisasi tujuan-tujuan kebijakan sebagai dampak dari kegiatan pemerintah. Keberhasilan maupun kegagalan implementasi dapat dievaluasi dari kemampuannya secara nyata dalam meneruskan atau mengoperasikan program yang telah direncanakan sebelumnya. Mengacu pendapat Grindle, keberhasilan maupun kegagalan implementasi dalam penelitian ini akan dilihat dari kemampuannya secara nyata dalam meneruskan atau mengoperasikan program Bantuan Operasional Sekolah (BOS), hambatan yang muncul serta solusi yang dilakukan.

Bantuan Operasional Sekolah merupakan program pemerintah yang pada dasarnya ditujukan untuk menyediakan biaya operasi nonpersonalia bagi satuan pendidikan dasar sebagai pelaksana program wajib belajar. Program Bantuan Opersional Sekolah (BOS) yang mulai diberlakukan sejak bulan Juli 2005, secara umum bertujuan untuk meringankan beban masyarakat terhadap pembiayaan pendidikan dalam rangka wajib belajar 9 (sembilan) tahun yang bermutu, serta berperan dalam mempercepat pencapaian Standar Pelayanan Minimal (SPM) pada sekolah yang belum memenuhi SPM, dan pencapaian Standar Nasional Pendidikan (SNP) pada sekolah yang sudah memenuhi SPM.Secara khusus program BOS bertujuan untuk: 1) membebaskan pungutan bagi semua peserta didik pada semua jenis SD negeri dan semua jenis SMP negeri terhadap biaya operasi sekolah; 2) membebaskan pungutan seluruh peserta didik miskin baik sekolah negeri maupun swasta dalam bentuk apapun; dan3) meringankan beban biaya operasi sekolah peserta didik di sekolah swasta. Pada tahun 2009 Poogram BOS mengalami perubahan tujuan, pendekatan serta orientasi, yaitu dari perluasan akses menuju pada peningkatan kualitas. Dalam perkembangannya, program 
BOS mengalami peningkatan biaya satuan dan juga perubahan mekanisme penyaluran pada setiap tahunnya, dan terhitung mulai pada tahun 2012 penyaluran dana BOS menggunakan mekanisme transfer ke provinsi yang selanjutnya ditransfer ke rekening sekolah secara langsung dalam bentuk hibah (Permendikbud No 16 tahun 2016).

Dana BOS(Bantuan Operasional Sekolah) ditujukanbagi semua sekolah SD (Sekolah Dasar)/SDLB (Sekolah Dasar Luar Biasa), SMP (Sekolah Menengah Pertama)/SMPLB (Sekolah Menengah Pertama Luar Biasa), danSatap (SDSMP Satu Atap), negeri dan swasta di seluruh Indonesia yang telah terdata dalam sistem Dapodikdasmen (Data Pokok Pendidikan Dasar dan Menengah). Bagi sekolah swasta, harus memiliki izin operasional. Besarnya dana yang diterima sekolah diseduaikan dengan jumlah peserta didik dengan besar satuan biaya untuk SD/ SDLB adalah sebesar Rp. 800.000,-/peserta didik/ tahun, sedangkan untuk SMP/SMPLB/Satap/ SMPT adalah sebesar Rp.1.000.000,-/peserta didik/tahun. Namun, dengan mempertimbangkan beberapa komponen biaya tetap (fix cost) dari biaya operasional sekolah tidak bergantung pada jumlah peserta didik, maka pemerintah menetapkan kebijakan khusus untuk sekolah dengan jumlah peserta didik kurang dari 60 (enam puluh) orang. Kebijakan khusus yang dimaksud adalah memberikan besar alokasi dana BOS sebanyak 60 (enam puluh) peserta didik, baik untuk sekolah tingkat SD maupun tingkat SMP. Sekolah yang menerima kebijakan ini adalah sekolah yang memenuhi kriteria sebagai berikut: 1) SD atau SMP yang termasuk dalam daerah khusus, sertadidirikan berdasarkan ketentuan dan syarat yang ditetapkan oleh pemerintah. Daerah khusus yang dimaksud adalah daerah yang diitetapkan Kementrian Desa, Pembangunan Daerah Tertinggal dan Transmigrasi; 2)Satap, SLB, SDLB dan SMPLB; 3)Sekolah di daerah kumuh atau daerah pinggiran yang peserta didiknya tidak dapat tertampung di sekolah lain di sekitarnya; atau 4) Khusus bagi sekolah swasta, sudah harus memiliki izin operasional minimal tiga tahun, dan juga bersedia tidak memungut biaya tambahan kepada seluruh peserta didik. Kebijakan ini tidak berlaku bagi sekolah dengan kriteria sebagai berikut: 1)Sekolah swasta yang menetapkan standar iuran/pungutan mahal; 2)
Sekolah swasta yang izin operasionalnya kurang dari 3 tahun; 3)Sekolah yang tidak diminati oleh masyarakat sekitar karena tidak berkembang, sehingga jumlah peserta didiksedikit dan masih terdapat alternatif sekolah lain di sekitarnya tyang masih dapat menampung peserta didik; 4) Sekolah yang terbukti dengan sengaja membatasi jumlah peserta didik dengan tujuan untuk memperoleh dana BOS dengan kebijakan khusus tersebut; atau5). Sekolah swasta yang tidak bersedia menerima kebijakan alokasi minimal (Permendikbud No 16 tahun 2016).

Pelaksanaan program BOS diatur dalam beberapa peraturan, yaitu: 1)PP(Peraturan Pemerintah) yang mengatur Rincian Anggaran Pendapatan dan Belanja Negara (APBN); 2) PMK (Peraturan Menteri Keuangan) sebagai pengatur mekanisme penyaluran dana BOS dari pusat ke provinsi dan pelaporannya; 3) Permendagri (Peraturan Menteri Dalam Negeri) yang mengatur mekanisme pengelolaan dana BOS di daerah dan mekanisme penyaluran dari kas daerah ke sekolah, dan 4)Permendikbud (Peraturan Menteri Pendidikan dan Kebudayaan) tentang petunjuk teknis penggunaan dan pertanggungjawaban keuangan dana BOS (Permendikbud No 16 tahun 2016).

Dana BOS disalurkan dari RKUN (Rekening Kas Umum Negara) ke RKUD (Rekening Kas Umum Daerah) setiap triwulan (tiga bulanan), yaitu triwulan I (Januari-Maret), triwulan II (April-Juni), triwulan III (Juli-September), dan triwulan IV (Oktober-Desember). Sekolah yang secara geografis sangat sulit atau berada pada wilayah terpencil sehingga proses pengambilan dana oleh sekolah mengalami hambatan/masalah serta memerlukan biaya pengambilan yang mahal, maka atas usulan pemerintah daerah dan persetujuan Kemendikbud, penyaluran dana BOS dilakukan setiap semester (setiap enam bulan), yaitu pada awal semester (Permendikbud No 16 tahun 2016).

Dana yang diterima sekolah, dapat digunakan untuk membiayai komponenkomponen kegiatan berikut: 1) Pengembangan perpustakaan; 2) Kegiatan penerimaan peserta didik baru; 3) Kegiatan pembelajaran dan ekstrakurikuler; 4) Kegiatan ulangan dan ujian; 5) Pembelian bahan habis pakai; 6) Langganan daya dan jasa; 7) Perawatan sekolah/rehab ringan dan sanitasi sekolah; 8) Pembayaran honorarium 
bulanan; 9) Pengembangan profesi guru dan tenaga kependidikan; 10) Membantu peserta didik miskin; 11) Pembiayaan pengelolaan sekolah; 12)Pembelian dan perawatan perangkat komputer; dan 13) Biaya lainnya (apabila seluruh komponen 1-12 telah terpenuhi) (Permendikbud No 16 tahun 2016).

Dana BOS yang diterima oleh sekolah tidak boleh digunakan untuk hal-hal berikut: 1) Disimpan dengan maksud dibungakan; 2) Dipinjamkan kepada pihak lain; 3) Membeli software/perangkat lunak untuk pelaporan keuangan BOS atau software sejenis; 4) Membiayai kegiatan lain bukan merupakan prioritas sekolah serta memerlukan biaya besar, misalnya studi banding, tur studi karya wisata) dan sejenisnya; 5) Membayar iuran kegiatan yang diselenggarakan oleh UPTD Kecamatan/ Kabupaten/ Kota/Provinsi/Pusat, atau pihak lainnya, kecuali untuk menanggung biaya peserta didik/ guru yang ikut serta dalam kegiatan tersebut; 6) Membayar bonus transportasi rutin untuk guru; 7) Membeli keperluan pribadi seperti pakaian, seragam, sepatu bagi guru atau peserta didik yang bukan merupakan inventaris sekolah, kecuali bagi peserta didik miskin yang tidak mendapat bantuan dari sumber lain; 8) Digunakan untuk rehabilitasi sedang dan berat; 9) Membangun gedungatauruangan baru; 10) Membeli Lembar Kerja Siswa (LKS) dan bahan/peralatan yang tidak mendukung proses pembelajaran; 11) Menanamkan saham; 12) Membiayai kegiatan lain yang dibiayai pemerintah pusat atau pemerintah daerah secara penuh atau wajar; 13)Membiayai kegiatan penunjang yang tidak berkaitan dengan operasi sekolah, seperti membiayai upacara kegamaan/acara keagamaan, dan iuran dalam rangka upacara peringatan hari besar nasional; 14) Membiayai kegiatan lain seperti sosialisasi, pelatihan, pendampingan berkaitan dengan program BOS atau perpajakan program BOS yang diselenggarakan lembaga di luar SKPD pendidikan Provinsi/Kabupaten/ Kota dan Kemendikbud; dan 15)Membayar honorarium kepada guru dan tenaga kependidikan atas tugas/kegiatan yang sudah merupakan tugas pokok dan fungsi yang telah diatur dalam peraturan perundangan yang berlaku, termasuk pembayaran honorarium bagi panitia untuk kegiatan-kegiatan yang sudah menjadi tupoksi sekolah/guru. Penggunaan dana BOS disekolah harus di dasarkan pada kesepakatan dan keputusan bersama antara Tim Manajemen BOS Sekolah, Dewan Guru dan Komite Sekolah. Hasil kesepakatan diatas harus dituangkan secara tertulis dalam bentuk berita acara rapat dan ditandatangani oleh peserta rapat. Kesepakatan penggunaan dana BOS harus didasarkan skala prioritas kebutuhan sekolah, khususnya untuk membantu mempercepat pemenuhan standar pelayanan minimal (SPM) dan/atau standar nasional pendidikan (SNP) (Permendikbud No 16 tahun 2016).

\section{KESIMPULAN DAN SARAN}

Implementasi program BOS dilihat pada tahap persiapan dan perencanaan pengelolaan BOS di sekolah sudah bagus hanya terkendala pada tidak diterbitkannya SK bagi tim manajemen BOS. Pada tahap penyaluran dana sudah sangat bagus karena sekolah melakukan sesuai dengan prosedur dan aturan yang ditentukan. Pada tahap pelaksanaan penggunaan dana BOS dari sekolah sudah sangat baik tetapi terkendala dengan terlambatnya pencairan dana dari pemerintah. Pada tahap pengawasan dilihat dari segi transparansi, sekolah sudah melibatkan komite dan orang tua siswa tetapi tidak mengumumkan laporan perencanaan penggunaan dana BOS sehingga mengurasi aspek transparansi yang diamanatkan dalam pedoman penggunaan BOS, dilihat dari segi akuntabilitas, sekolah menyusun perencanaan penggunaan dana BOS sesuai dengan format yang diberikan Dinas Pendidikan, sekolah juga tertib dalam administrasi laporan pertanggungjawaban penggunaan dana tetapi dengan tidak diumumkannya laporan perencanaan penggunaan dana BOS mengurasi aspek akuntabilitas yang diamanatkan dalam pedoman penggunaan BOS.

Berdasarkan kesimpulan di atas, beberapa saran agar implementasi penggunaan dana BOS kedepannya menjadi lebih baik yaitu: 1) Sekolah harus mempelajari panduan penggunaan dana BOS secara mendalam sehingga pelaksanaannya pun maksimal dan sesuai; 2) Tim Manajemen BOS Kabupaten dalam memberikan materi sosialisasi tidak hanya terfokus pada masalah-masalah keuangan tetapi juga mencakup tertib administrasi sesuai panduan; 3) Kementrian Pendidikan Nasional dalam penyusun standar operasional program perlu melakukan kajian berkelanjutan 
tentang kebutuhan nyata operasional sekolah, agar rambu-rambu penggunaan dana BOS dapat lebih sesuai atau mendekati kebutuhan sekolah dan mengusahakan ketepatan dalam penyaluran dana BOS kepada setiap sekolah.

\section{DAFTAR RUJUKAN}

Lika. 2016. Implementasi Program Bantuan Operasional Sekolah (BOS) Pada Sekolah dasar Negeri 003 Melak Kabupaten Kutai Barat. eJournal Ilmu Pemerintahan Vol 4 No 3.

Peraturan Menteri Pendidikan Dan Kebudayaan Nomor 16 Tahun 2016 Tentang Perubahan Atas Peraturan Menteri Pendidikan dan Kebudayaan Nomor 80 Tahun 2015 Tentang Petunjuk Teknis Penggunaan Dan Pertanggungjawaban Keuangan Dana Bantuan Operasional Sekolah.

Purwanti.2014. Keefektifan Peran Guru sebagai Pendidik dan Bendahara Bantuan Operasional Sekolah. Manajemen Pendidikan, Volume 24, Nomor 4, September 2014, p.350-356.
Setyorini, Ninik Purwaning. 2010. Implementasi Program Bos 2009 Di Sekolah Negeri Pada Komisariat SMPN 1 Bojonggede, Kabupaten Bogor. Tesis. Universitas Indonesia. Jakarta.

Sugiyono. 2015. Metode Penelitian Manajemen. Bandung: Alfabeta.

Undang-Undang Dasar Republik Indonesia Tahun 1945.

Undang-Undang Republik Indonesia No 20 Tahun 2003 Tentang Sistem Pendidikan Nasional.

Winarno, Budi. 2002. Kebijakan Publik: Teory dan Praktik. Yogyakarta: Media Pressindo

Yusuf, Muhammad dan Ikhsani. 2014. Evaluasi Penggunaan Program 2 Shift pada Pembelajaran Praktik Pemesinan di SMK Pangudi Luhur Muntilan. Universitas Negeri Yogyakarta. 